\title{
Internal Audit Function Quality and Audit Committees' Practices: Survey Evidence from Jordan
}

\author{
Fawzi A. Al Sawalqa (Corresponding author) \\ Accounting Department, Business Faculty \\ Tafila Technical University, Box 179, Tafila 66110, Jordan \\ Tel: 962-772-282-190Ｅ-mail: fsawalqah@ttu.edu.jo
}

\begin{abstract}
Atala Qtish
Accounting Department, Economics \& Administrative Sciences Faculty

Al-Zaytoonah University, Amman, Jordan

E-mail: atala.q@zuj.edu.jo
\end{abstract}

Received: February 1, 2021 Accepted: March 4, $2021 \quad$ Published: March 20, 2021

doi:10.5296/ber.v11i2.18263 URL: https://doi.org/10.5296/ber.v11i2.18263

\begin{abstract}
The current study examines the extent to which audit committees comply with the requirements of corporate governance in Jordan and describes the current status of internal audit function. In addition, the study examines empirically the relationship between the internal audit quality and the compliance of audit committees with the governance requirements. The results from 49 respondents indicate that audit committees comply with the requirement of corporate governance and no significant difference is found in such compliance due to sector. In addition, the internal audit quality attributes are met among Jordanian companies to a considerable extent. Further, the independence and objectivity dimension of internal audit quality has a positive and significant relationship with the compliance of audit committees with governance requirements. Internal audit competence and due professional care have no significant relationship with audit committees compliance. One important implication of the current study is the development of a scale to measure the compliance level of audit committees with the governance requirements that can be used by both academics and decision-makers in firms.
\end{abstract}

Keywords: Internal audit quality, Independence, Objectivity, Competence, Due professional care, Audit committee 


\section{Introduction}

A considerable attention has been given to internal auditing profession recently (e.g. Desai, Roberts \& Srivastava, 2010; Karagiorgos, Giovanis, \& Drogalas, 2011), due to the rapid change in the business environment (Savčuk, 2007), the appearance of corporate governance instructions and the role that internal audit plays in applying such instructions (Arena \& Azzone, 2009). Therefore, it is reasonable to argue that internal audit has its significant mission in the current business market and deals not only with accounting issues within the firm, but also controls and monitors all the aspects of management activities (Savčuk, 2007) and corporate governance practices (Davies, 2009). For example, ISA No. 610 (IAASB, 2013) along with SAS No. 128 (AICPA, 2014) tried to arrange the relationship between the internal auditor and external auditor by outlined the main conditions that enable the external auditor to depend on the work of internal auditor with some emphasis on the three internal auditing features; objectivity, competence and work performance (see also, AICPA, 2020).

However, the effectiveness and challenges that face internal audit profession have been investigated, especially in developed countries. This is because a good internal audit means a strong internal control, a low risk and consequently a good governance practices (Vasile \& Croitoru, 2012). Similarly, Balkaran (2013) summarized the importance of corporate governance to any organization in that it arranges the different aspects of work in the firm and integrates all the available efforts to achieve the intended objectives. Therefore, it can be argued that there is an interrelated relationship between internal audit and corporate governance through the audit committees. However, previous studies in the field have identified the different aspects of internal audit quality, but unfortunately have ignored its effect on the corporate governance practices. In this regard, Tušek (2015) argued that the communication between audit committee and internal audit function offers essential information to audit committee, which in turn strengths the corporate governance practices and supports a firm to achieve its objectives. Therefore, quality of internal audit function is important factor to ensure good governance practices. For example, the independence of internal auditor according to agency theory is a critical tool for board of directors to ensure the quality of financial reporting in any firm (Christopher et al., 2009). In addition, other internal audit quality attributes are also contribute significantly toward reporting quality (e.g. Abbott, Daugherty, Parker \& Peters, 2016; Drogalas, Arampatzis \& Anagnostopoulou, 2016). The current study focuses mainly on the role of internal audit in enhancing the governance practices. The justification of such focus is based on the critical role that good corporate governance plays in protecting the rights of different stakeholders in any firm, which in turn decreases the conflict of interests among the different parties and contributes effectively toward a good performance as suggested by agency theory (Jensen, 1993). Accordingly, the current study comes to achieve the following objectives:

1. Determining the extent to which audit committees comply with the requirements of corporate governance In Jordan.

2. Describing the current status of internal audit quality. 
3. Examining the relationship between the internal audit quality and the compliance of audit committees with the requirements of corporate governance of Jordanian listed companies.

The current study contributes to current knowledge by developing new scale to evaluate the extent to which audit committee comply with corporate governance practices and offers an additional evidence on the effect of internal audit function on such practices. The study also shows the importance of communication between audit committees and internal audit departments to support the efforts of board of directors in protecting the rights of shareholders and monitoring the activities of firms.

The next section of this paper discusses the internal audit profession and audit committees' practices as outlined in corporate governance instructions. Section three offers the theoretical frameworks of the study. Section four reviews the prior studies in the field. Section five describes the methods used in the study. Section six discusses the results and finally section seven concludes the study.

\section{Audit Profession and Audit Committees in Jordan}

Jordan organized the internal auditing profession through the Institute of Internal Auditors Jordan (IIA Jordan) which is affiliated to the Institute of Internal Auditors (Global) and the main mission of it is to promote the adoption of international standards for the professional practice of internal auditing in Jordanian organizations and to serve its members (IIA Jordan, 2021). The IIA Jordan has not the enforcement power to enforce Jordanian companies to adopt the international standards for the professional practice of internal auditing. However, the adoption of corporate governance practices among Jordanian companies contributes significantly in developing the internal audit profession. For example, the audit committee in Jordanian listed companies has the power to monitor and evaluate the internal auditing activities and has the power to nominate a relevant person to be the internal auditor of the entity (JSC, 2017).

Jordan has developed the corporate governance instructions in order to prepare firms to compete through best practices in the business market. Lately, Jordan Securities Commission (JSC) issued new instructions for corporate governance effective from May 22, 2017. The current study focuses on the relationship between internal audit function and audit committee practices. The new corporate governance instructions give more emphasis to such relationship. The new instructions include all the necessary rules that related to the duties and powers of audit committee. For example, the audit committee should include at least three non-executive members and two of them at least must be independent (JSC, 2017). The instructions also stress the importance of previous experiences and qualifications of audit committee members, especially in accounting and other related fields (JSC, 2017). Accordingly, it can be argued that Jordan follows-to a considerable extant- the Anglo-American (also called Anglo-Saxon) model of corporate governance practices in this instant (e.g. Ahmad \& Omar, 2016; Krenn, 2015). The instructions also interested on the role of audit committee in mentoring and evaluating the internal audit activities as outlined in Article (7) of 2017 corporate governance instructions (JSC, 2017). 


\section{Theoretical Frameworks}

The accounting scandals and financial crisis have contributed toward the development of audit profession and corporate governance especially in developed countries (e.g. Agrawal \& Chadha, 2005; Brown \& Caylor, 2006; Coram et al., 2008; Beattie et al., 2012; Byrne, 2014; Chambers, 2014; Kwon et al., 2014; Williams et al., 2015). In this context, prior studies' findings (e.g. Agrawal \& Chadha, 2005; Carcello et al., 2005) show a significant change in internal audit profession and corporate governance practices following the accounting scandals and financial crisis in several firms. The main development was the appearance of Sarbanes-Oxley Act in 2002 in USA which put more emphasis on the corporate governance practices and financial reporting (e.g. Agrawal \& Chadha, 2005; Damitio et al., 2010; Kwon et al., 2014; Sun et al., 2015; Ahmad \& Omar, 2016). However, much emphasis has been given to external audit profession and more attention has been also given to internal audit profession in previous studies due to its critical role in ensuring a good governance practices (e.g. Pathak, 2004; Turley \& Zaman, 2004; Coram et al., 2008; Arena \& Azzone, 2009; Christopher, 2012; Vasile \& Croitoru, 2012; Arena \& Jeppesen, 2016). The role of internal audit currently is expanded to evaluate the "risk, control" and "governance practices" (Christopher, 2012, p. 531). The communication between the board of director and internal auditor is usually performed through the audit committee (Sarens, De Beelde \& Everaert, 2009; Stewart \& Subramaniam, 2010). In this context, the Institute of Internal Auditors (IIA) explains in details the objectives of internal auditing and also gives more emphasis to the role of good internal auditing in ensuring good corporate governance practices (IIA, 2016). In particular, IIA proposes that, "the internal audit activity helps an organization accomplish its objectives by bringing a systematic, disciplined approach to evaluate and improve the effectiveness of governance, risk management and control processes" (IIA, 2016, p.23). This is also clear in the definition of internal auditing as " $a$ department, division, team of consultants, or other practitioner(s) that provides independent, objective assurance and consulting services designed to add value and improve an organization's operations" (IIA, 2016, p.23). In the same context, IIA defined governance as, "the combination of processes and structures implemented by the board to inform, direct, manage, and monitor the activities of the organization toward the achievement of its objectives" (IIA, 2016, p.23). Therefore, it can be argued that both internal audit function and governance try to control the different activities of a firm to effectively achieve its goals.

Extant research has been focused on internal audit and discussed, for example, the extent of reliance on the work of internal auditors by external auditors through evaluating the internal audit quality perspectives (i.e. objectivity, competence and work performance) in Margheim (1986), the effect of inherent risk on the external auditor decision to depend on the work of internal auditor in Maletta (1993), the relationship between the internal audit function in Desai, Roberts and Srivastava (2010), the determinants of internal auditing effectiveness in Arena and Azzone (2009) and Cohen and Sayag (2010), the relationship between the internal audit function and the external audit fee in Mohamed, Zain, Subramaniam and Yusoff (2012), the extent of reliance on the work of internal auditors by external auditors in Abbott, Parker and Peters (2012), the determinants of the quality of internal auditing services in Lélis and 
Pinheiro (2012), and the extent to which external auditors reliance on internal audit function at the existence of continuous auditing in Davidson et al. (2013) in USA.

\section{Literature Review}

This section focuses on the prior studies that interested in the relationship between internal audit function quality and corporate governance practices with more emphasis on the role of audit committee. However, very few studies have investigated the growing role of internal audit in improving governance practices in emerging markets such as Jordan. Nevertheless, more attention has been given to the relationship between internal audit and governance practice in developed countries. For example, Goodwin (2003) found that the experience and independence of audit committee in Australia and New Zealand have no direct effect on internal audit but their effect appear when linked with other firm characteristics such as sector type. Paape et al. (2003) conducted a study to assess the relationship between internal audit function and corporate governance in the European Union and found that the relationship was not so good due to several weaknesses. Authors' findings indicated that many governance practices and internal audit standards are missed in some countries. Zain and Subramaniam (2007) found a weak interaction between internal auditors and audit committee in Malaysia. Christopher et al. (2009) conducted a study to investigate the extent of independence of internal audit function in respect to its relationship with management and audit committee in Australia and found that internal audit function is not complied with the requirements of the IIA in reporting in that some reports are not directed to audit committees. Authors' findings also show that the management in some companies carried out the responsibility of hiring the head of internal audit function and has important role in determining the internal audit budget and audit plan. Abbott, Parker and Peters (2010) found a positive relationship between audit committee and internal audit activities. Ebaid (2011) found, for example, that lack of independence affect the role of internal audit functions in maintaining good corporate governance practices among Egyptian firms. Christopher (2012) investigated the role of internal audit as a control mechanism in improving the governance practices among Australian public universities and found that internal auditors are not involved enough in controlling several management activities in universities (see also, Turley \& Zaman, 2004). Sarens et al. (2012) investigated the potential role of internal audit function in corporate governance practices among a sample of USA companies and found that many factors supported the role of internal audit function in corporate governance, especially in listed companies such as the availability of relevant skills and the communication channels with the members of audit committee. Suyono and Hariyanto (2012) found a positive and significant relationship between internal audit and corporate governance of Indonesian companies. Similar result was found by Drogalas, Arampatzis and Anagnostopoulou (2016) in respect to Greece firms. Zaman and Sarens (2013) found that additional collaboration between the internal audit functions and audit committee in UK firms is positively impacted internal audit quality attributes. Similar result was found by Tušek (2015) in Croatia. Amin and Burki (2014) found that internal audit process and interaction with business managers have positively and significantly impacted corporate governance practices of Pakistani banks. Bilal, Twafik and Bakhit (2018) examined the effect of internal audit on the corporate governance practices 
among Omani banks and found that internal audit independence, competence and due professional care, and nature of work have a positive and significant relationship with corporate governance (see also, Alzeban \& Sawan, 2015). Alzeban (2020) found that audit committee independence facilitates the relationship between the independence of internal audit and the performance of firms. Khalid (2020) investigated the relationship between governance committees and internal audit in Islamic banks of Bahrain and suggested that audit and governance committees may have some effect on internal audit of such Islamic banks (see also, Alzeban, 2020).

In general, prior studies that focused mainly on internal audit function and audit committee practices are few and most of them have not directly examined such relationship. In addition, some prior studies have not taken the different dimensions of internal audit quality, and have employed scattered indicators to measure the quality. Furthermore, some prior studies have used very few indicators to measure the corporate governance and audit committee practices. In contrast, the current study examines directly the relationship between three main internal audit function dimension and audit committee practices as outlined in Jordanian instructions of corporate governance.

\section{Research Design}

This section offers the method used in the current study in terms of the study sample and instrument along with the descriptive statistics of the respondents. In addition, the section shows the measurement of study variables in some detail.

\subsection{Sample Selection}

The study population includes all the Jordanian companies that listed on ASE. Due to presence of the COVID-19 Pandemic, only 70 questionnaires were handed to listed companies. The 70 companies were selected randomly from 180 listed companies. The Arabic version of questionnaire was directed to the internal auditors or financial managers of such companies. The development of questionnaire based mainly on two main sources including; the 2017 Corporate Governance Instructions for Shareholding Companies Listed on the ASE, which issued by JSC, and effective from May 22, 2017, and the 2016 International standards for the professional practice of internal auditing (Standards), which issued by IIA and effective from January 2017. In addition, some of the questionnaire items were adapted from prior studies in the field. All the main questions are close-ended and measured on a five-point likert scale. Considerable efforts were performed and resulted on collecting 68 questionnaires. 19 unusable questionnaires were excluded. This yielded 49 usable questionnaires. As shown in Table 1, about $91.8 \%$ of the respondents are males. This result is less than that of Ebaid (2011) who found that $100 \%$ of respondents were males. Most of the respondents $(83.7 \%$ ) aged 30 years or above. In addition, $71.3 \%$ of the respondents have experience of 5 years or above in the firm. About $63.3 \%$ of the respondents have accounting degrees. The respondents are also well-educated as most of them (89.8\%) have bachelor degree or above. Finally, the sample of the study is distributed over three sectors including industry, services and insurance. 
Table 1. Demographic statistics of respondents

\begin{tabular}{|l|l|l|l|l|l|}
\hline Demographic & Frequency & $\%$ & Demographic & Frequency & $\%$ \\
\hline Gender & & & Majoring & & \\
\hline Male & 45 & 91.8 & Accounting & 31 & 63.3 \\
\hline Female & 4 & 8.2 & Business Administration & 9 & 18.4 \\
\hline Total & 49 & 100.0 & Economy & 6 & 12.2 \\
\hline Age & & & Finance & 3 & 6.1 \\
\hline less than 30 & 8 & 16.3 & Total & 49 & 100.0 \\
\hline 30- less than 40 & 8 & 16.3 & Position & & \\
\hline 40-less than 50 & 23 & 47.0 & Financial manager & 18 & 36.7 \\
\hline 50 years or above & 10 & 20.4 & Internal auditor & 31 & 63.3 \\
\hline Total & 49 & 100.0 & Total & 49 & 100.0 \\
\hline Experience & & & Qualification & & \\
\hline less than 5 & 14 & 28.6 & PhD & 3 & 6.1 \\
\hline 5-less than 10 & 19 & 38.8 & MSc & 12 & 24.5 \\
\hline 10-less than 15 & 11 & 22.4 & BSc & 29 & 59.2 \\
\hline 15-less than 20 & 1 & 2.0 & Diploma & 5 & 10.2 \\
\hline 20-less than 30 & 1 & 2.0 & Total & 49 & 100.0 \\
\hline 30 years or above & 3 & 6.1 & & & \\
\hline Total & 49 & 100.0 & & & \\
\hline Sector & & & & & \\
\hline Industry & 14 & 28.6 & & & \\
\hline Services & 23 & 46.9 & & & \\
\hline Insurance & 12 & 24.5 & & & \\
\hline Total & 49 & 100.0 & & & \\
\hline
\end{tabular}

\subsection{Measurement of Variables}

The study instrument includes four sections (see the Appendix). The first section focuses on the demographic characteristics of the respondents. The second section focuses on the extent to which audit committees of Jordanian listed companies comply with the requirements of corporate governance practices. To measure the extent to which audit committee complies with the requirements of corporate governance practices of Jordanian listed companies, 15 questions were derived from Article 7 of 2017 Corporate Governance Instructions for Shareholding Listed Companies which issued by JSC, and used from May 22, 2017 (JSC, 2017, paragraphs. A, D, E, pp. 14-17). However, considerable efforts were performed to extract such indicators and to offer new scale for future studies in this field.

Sections three and four have 20 questions interested in measuring internal audit quality. Prior studies in the field used several approaches to measure the internal audit quality. Examples include using objectivity or independence, competence and work performance in Margheim (1986); Maletta (1993); Desai, et al. (2010) and Prawitt et al. (2012), objectivity and competence in Abbott et al. (2012) and Prawitt et al. (2011), competency and contribution to financial statement audit in Mohamed et al. (2012), objectivity, competence and the technical skills of internal auditor in Davidson et al. (2013). Others such as Cohen and Sayag (2010) considered the audit quality as a component of internal audit effectiveness and measured it based on 12 items derived from prior studies in the field. Another approach was used by Arena and Azzone (2009) and based on the level of implementation of the internal auditor 
recommendations. Others such as Lélis and Pinheiro (2012) stressed the importance of considering control, risk and governance in measuring audit quality. Therefore, it can be concluded that there is no one common measure for internal audit quality in previous literature. Nevertheless, there is some compatibility on using some common attributes to measure the internal audit quality in previous studies such as objectivity, competency and due professional care. Accordingly the current study measures the internal audit function quality based on three attributes of internal audit quality namely independence and objectivity, competency and due professional care. Specifically, the current study depends on the International Standards for the Professional Practice of Internal Auditing (STANDARDS)" which issued by IIA and applied from January 2017 in measuring the internal audit function quality (IIA, 2016). According to IIA (2016, p. 2) the internal auditor should comply with the standards related to, "individual objectivity, competency and due professional care and the standards relevant to the performance of their job responsibilities". However, section three has 17 questions used to measure the objectivity, competence and due professional care. 13 questions were derived from IIA (2016, pp. 5-7). 5 questions related to objectivity in terms of simplicity of conducting the work, absence of mutual interests and simplicity of accessing several resources IIA (2016, p. 5). 3 questions that are related to competency or proficiency focused on professional qualification and knowledge IIA (2016, p. 6). 5 questions related to due professional care in terms of evaluation the different issues that related to the work such as scope, cost, techniques and risks IIA (2016, p. 7). In addition, 4 questions related to competency were adapted from prior research in the field (e.g. Al-Thuneibat et al., 2016, p. 30) and include, "the internal auditors have qualifications in accounting or related fields, the internal auditors have sufficient experience in accounting and auditing, internal auditors participate in ongoing education and training courses and internal auditors have sufficient knowledge in the accounting and auditing standards". Section four interested in measuring the internal audit function independence. As suggested by Alzeban (2020), three questions were used to measure the internal audit function independence. One question that related to the reporting process was adapted from Al-Thuneibat et al. (2016, p.30). The other two questions including, "There is nothing that may impair in fact or appearance the independence of the internal auditor" (IIA 2016, p. 5), and "There are no restrictions to limit the ability of internal auditors to do their work without any bias" (IIA 2016, p. 3).

\subsection{Study Hypotheses}

Four hypotheses were developed. These include:

H1. There is no significant difference in the compliance of audit committee with requirement of corporate governance due to sector.

Consistent with the recommendation of IIA (2016) and the findings of prior studies in the fields (e.g. Sarens et al., 2012; Suyono \& Hariyanto, 2012; Tušek, 2015; Bilal, Twafik \& Bakhit, 2018), the current study proposes a positive and significant relationship between the several dimensions of internal audit quality and the audit committee practices through the following three alternative hypotheses:

H2. Internal audit independence and objectivity have a positive and significant impact on the 
audit committee practices.

H3. Internal audit competence has a positive and significant impact on the audit committee practices.

H4. Internal audit due professional care has a positive and significant impact on the audit committee practices.

\section{Results and Discussion}

Based on the objectives of the study, this section shows the results of the study in terms of descriptive statistics and the regression analysis.

\subsection{Descriptive Statistics}

The descriptive statistics were used to achieve the first two objective of the current study.

\subsubsection{Audit Committee Compliance with Corporate Governance Requirements}

The first objective of the current study seeks to determine the extent to which audit committees comply with the requirements of corporate governance in Jordan. Table 2 shows that all the 15 requirements are seriously employed by the audit committees in Jordan. On a five-point-likert scale, the mean values ranged from 4.7347 to 4.2041 , with a total mean value of 4.3769. It looks that audit committee members have the necessary accounting and financial knowledge as the first two requirements dealing with the accounting and financial certificates and experience, with mean values of 4.7347 and 4.6122 respectively. Setting out the strategies of internal control and discussing the nomination issue of external auditor ranked third, with a mean value of 4.4694 for both requirements. Similarly, mentoring the activities of external auditor ranked fifth, with a mean of 4.4082. Preventing conflicts with related parties ranked sixth, with a mean of 4.3878. Monitoring the responses of management to external auditor comments ranked seventh with a mean value of 4.3469 . Evaluating the procedures of internal control and auditing ranked eighth, with a mean value of 4.3265 . Recommending to the board of director in issues like internal control, internal audit and the internal auditor work ranked ninth. Similarly, recommending to the board of director to nominate the external auditor for election by the General Assembly ranked ninth. Other requirements also have closed mean values. These results depend on a well-developed scale extracted from the 2017 governance instructions in Jordan. The 15 indicators are new addition to the knowledge in the field and can be validated and used in future studies to measure the audit committee compliance level with governance instructions. Notably that these indicators are in line with the international principles of corporate governance (OECD, 2015). 
Table 2. Audit committee compliance with the requirements of corporate governance practices

\begin{tabular}{|c|c|c|c|}
\hline Requirement & Rank & Mean & S.D. \\
\hline $\begin{array}{l}\text {-At least one of the audit committee members has an academic or professional } \\
\text { certificate in accounting, finance or related fields. }\end{array}$ & 1 & 4.7347 & .44607 \\
\hline $\begin{array}{l}\text {-All members of the Audit Committee have knowledge and experience in financial } \\
\text { and accounting issues. }\end{array}$ & 2 & 4.6122 & .53293 \\
\hline $\begin{array}{l}\text {-The audit committee sets out the polices and strategies necessary to improve the } \\
\text { internal control in the company. }\end{array}$ & 3 & 4.4694 & .54398 \\
\hline $\begin{array}{l}\text { - The audit committee discusses matters related to the nomination of the external } \\
\text { auditor, ensures that he fulfils all the requirements specified in legislations, and } \\
\text { makes sure that there is nothing affects his independence. }\end{array}$ & 3 & 4.4694 & .64878 \\
\hline $\begin{array}{l}\text {-The audit committee discusses and monitors everything related to the work of the } \\
\text { external auditor, including his work plan. }\end{array}$ & 5 & 4.4082 & .53690 \\
\hline $\begin{array}{l}\text { - The audit committee takes all the necessary procedures to ensure that no conflict } \\
\text { of interest may arise from the company's transactions, contracts or projects with } \\
\text { related parties. }\end{array}$ & 6 & 4.3878 & .78571 \\
\hline $\begin{array}{l}\text {-The audit committee monitors the company's management response to the } \\
\text { external auditor comments, and accordingly makes recommendations to the board } \\
\text { of directors. }\end{array}$ & 7 & 4.3469 & .56092 \\
\hline $\begin{array}{l}\text {-The audit committee studies and evaluates the internal control and auditing } \\
\text { procedures. }\end{array}$ & 8 & 4.3265 & .47380 \\
\hline $\begin{array}{l}\text {-The audit committee recommends to the board of directors regarding internal } \\
\text { control, internal audit and the internal auditor work. }\end{array}$ & 9 & 4.3061 & .50843 \\
\hline $\begin{array}{l}\text {-The Audit Committee recommends to the board of directors to nominate the } \\
\text { external auditor for election by the General Assembly. }\end{array}$ & 9 & 4.3061 & 61928 \\
\hline $\begin{array}{l}\text {-The audit committee reviews the related parties' transactions and recommends to } \\
\text { the board of directors prior to their ratification by the company. }\end{array}$ & 11 & 4.2857 & .79057 \\
\hline $\begin{array}{l}\text {-The audit committee reviews the external auditor's evaluation of internal control } \\
\text { and auditing procedures. }\end{array}$ & 11 & 4.2857 & .50000 \\
\hline $\begin{array}{l}\text {-The audit committee examines the periodic reports prior to their presentation to } \\
\text { the board of directors, and makes recommendations in this regard, with emphasis } \\
\text { on any change in the accounting policies and accounts due to the auditing or the } \\
\text { suggestions of the external auditor. }\end{array}$ & 13 & 4.2653 & .49056 \\
\hline $\begin{array}{l}\text {-The audit committee reviews the internal auditor's reports, with emphasis on any } \\
\text { violations due to the internal auditor's work. }\end{array}$ & 14 & 4.2449 & .48004 \\
\hline $\begin{array}{l}\text {-The Audit Committee recommends to the Board of Directors to appoint an } \\
\text { internal auditor for the Company. }\end{array}$ & 15 & 4.2041 & .73540 \\
\hline Total & & 4.3769 & \\
\hline
\end{tabular}

\subsubsection{Internal Audit Function Quality}

To achieve the second objective of the current study, The internal audit quality was measured using 20 quality indicators derived mainly from International Standards for the Professional Practice of Internal Auditing (IIA, 2016) and some prior research in the field (e.g. Al-Thuneibat et al., 2016). These indicators are distributed over four quality perspectives including individual objectivity, independence, competence and due professional care. As shown in Table 3, Jordanian firms comply with the internal audit indicators. In particular, the simplicity of performing duties ranked first with a mean value of 4.5510 on a five-point-likert scale. This followed by the absence of any personal benefits with a mean of 4.5306 . Having 
professional certificates and the necessary experiences in accounting and auditing are ranked third, with a mean value of 4.5102 for both of them. Confidence of firms in their internal auditors ranked fifth with a mean value of 4.4694. Having accounting or related fields' qualifications is ranked sixth with a mean value of 4.4286. Determining the needed work to achieve the auditing objectives ranked seventh. Both evaluating the possibility of major errors and having adequate knowledge in technology-based audit techniques ranked eighth with a mean value of 4.3878 for both of them. In general, Table 3 shows that all the 20 indicators have higher mean values. This indicates that Jordanian companies comply with the internal audit quality indicators and IIA requirements. The overall mean value for the internal audit quality indicators is 4.3469 . However, these results are in line with the findings of Sarens et al. (2012), but contradict that of Christopher et al. (2009), who found several weaknesses in internal audit function. 
Table 3. Internal audit function quality indicators

\begin{tabular}{|c|c|c|c|c|}
\hline Quality indicator & Perspective & Rank & Mean & S.D. \\
\hline $\begin{array}{l}\text {-The internal auditors can easily and impartially perform their } \\
\text { duties in the company. }\end{array}$ & Objectivity & 1 & 4.5510 & .50254 \\
\hline $\begin{array}{l}\text {-The internal auditors have not any personal interests in the } \\
\text { company. }\end{array}$ & Objectivity & 2 & 4.5306 & .54398 \\
\hline $\begin{array}{l}\text {-Some of the internal auditors' members have appropriate } \\
\text { professional certificates. }\end{array}$ & Competency & 3 & 4.5102 & .50508 \\
\hline $\begin{array}{l}\text {-The internal auditors have sufficient experience in accounting } \\
\text { and auditing. }\end{array}$ & Competency & 3 & 4.5102 & .50508 \\
\hline $\begin{array}{l}\text {-The company has full confidence that the internal auditors are } \\
\text { doing their job perfectly. }\end{array}$ & Objectivity & 5 & 4.4694 & .54398 \\
\hline $\begin{array}{l}\text {-The internal auditors have qualifications in accounting or } \\
\text { related fields. }\end{array}$ & Competency & 6 & 4.4286 & .50000 \\
\hline $\begin{array}{l}\text {-The internal auditors determine the extent of work needed to } \\
\text { achieve the auditing objectives. }\end{array}$ & $\begin{array}{l}\text { Professional } \\
\text { care }\end{array}$ & 7 & 4.4082 & .49659 \\
\hline $\begin{array}{l}\text {-The internal auditors evaluate the possibility of major errors, } \\
\text { fraud, or noncompliance. }\end{array}$ & $\begin{array}{l}\text { Professional } \\
\text { care }\end{array}$ & 8 & 4.3878 & .49229 \\
\hline $\begin{array}{l}\text {-Some internal auditors have adequate knowledge of the major } \\
\text { IT risks and technology-based audit methods available to } \\
\text { perform their duties. }\end{array}$ & Competency & 8 & 4.3878 & .60609 \\
\hline $\begin{array}{l}\text {-There is nothing that may impair in fact or appearance the } \\
\text { independence of the internal auditor. }\end{array}$ & Independence & 10 & 4.3673 & .56620 \\
\hline $\begin{array}{l}\text {-The internal auditors use the technology-based audit and other } \\
\text { data analysis techniques. }\end{array}$ & $\begin{array}{l}\text { Professional } \\
\text { care }\end{array}$ & 11 & 4.3469 & .59690 \\
\hline $\begin{array}{l}\text {-Internal auditors have sufficient knowledge in the accounting } \\
\text { and auditing standards. }\end{array}$ & Competency & 11 & 4.3469 & .56092 \\
\hline $\begin{array}{l}\text {-The Internal auditors have adequate knowledge to evaluate } \\
\text { various types of risks. }\end{array}$ & Competency & 13 & 4.3265 & .51590 \\
\hline $\begin{array}{l}\text {-The internal auditors can easily access to records, personnel } \\
\text { and properties of the company. }\end{array}$ & Objectivity & 14 & 4.3061 & .61928 \\
\hline $\begin{array}{l}\text {-There are no restrictions to limit the ability of internal auditors } \\
\text { to do their work without any bias. }\end{array}$ & Independence & 14 & 4.3061 & .61928 \\
\hline $\begin{array}{l}\text {-The internal auditors evaluate the cost of any procedure } \\
\text { against its expected benefits. }\end{array}$ & $\begin{array}{l}\text { Professional } \\
\text { care }\end{array}$ & 16 & 4.2857 & .54006 \\
\hline $\begin{array}{l}\text {-The internal auditors evaluate the sufficiency and effectiveness } \\
\text { of governance, risk management, and control processes. }\end{array}$ & $\begin{array}{l}\text { Professional } \\
\text { care }\end{array}$ & 17 & 4.2449 & .56016 \\
\hline $\begin{array}{l}\text {-Internal auditors participate in ongoing education and training } \\
\text { courses. }\end{array}$ & Competency & 18 & 4.1224 & .78083 \\
\hline $\begin{array}{l}\text {-The company offers the sufficient funds for the internal } \\
\text { auditors to perform their duties effectively. }\end{array}$ & Objectivity & 19 & 4.1020 & .68450 \\
\hline -The internal auditors report directly to the board of director & Independence & 20 & 4.0000 & .84163 \\
\hline Total & & & 4.3469 & \\
\hline
\end{tabular}

Table 4 also shows the descriptive statistics for the four main dimensions of the internal audit quality. It looks that the objectivity is the dominant with a mean value of 4.3918 . This means that Jordanian companies give more emphasis to the objectivity in internal audit. As shown in Table 3 above, the first two indicators are related to objectivity. However, the competency dimension comes second with a mean value of 4.3761., the due professional care dimension comes third with a mean value of 4.3347 . Finally, independence comes fourth with a mean 
value of 4.2245 .

Table 4. Descriptive statistics for the audit quality dimensions

\begin{tabular}{|l|l|l|l|}
\hline Dimension & No. of indicators & Mean & S.D. \\
\hline Individual objectivity & 5 & 4.3918 & .36506 \\
\hline Competence & 7 & 4.3761 & .29979 \\
\hline Due professional care & 5 & 4.3347 & .37724 \\
\hline Independence & 3 & 4.2245 & .52435 \\
\hline
\end{tabular}

\subsection{Hypotheses Testing Results}

To examine if there is a difference in compliance of audit committee with the requirement of corporate governance from one sector to another, One Way ANOVA test is employed. In particular, H1 proposes that there is no significant difference in the compliance of audit committee with requirement of corporate governance due to sector. As shown in Table 5, the mean value is not significant $(\mathrm{F}=0.552 ; \mathrm{p}>0.05)$. Accordingly, $\mathrm{H} 1$ is accepted. This means that the compliance of audit committees in Jordanian companies is not difference from one sector to another. Linking this result with the results of descriptive statistics reveals that audit committees in all the study sectors are complied with the governance practices in Jordan.

Table 5. One Way ANOVA test

\begin{tabular}{|l|l|l|l|l|l|l|}
\hline Factor & & Sum of Squares & df & Mean Square & F & Sig. \\
\hline \multirow{3}{*}{ Sector } & Between Groups & 0.080 & 2 & 0.040 & 0.552 & 0.580 \\
\cline { 2 - 7 } & Within Groups & 3.338 & 46 & 0.073 & & \\
\cline { 2 - 7 } & Total & 3.418 & 48 & & & \\
\hline
\end{tabular}

The rest of hypotheses ( $\mathrm{H} 2, \mathrm{H} 3$ and $\mathrm{H} 4)$ will be tested using the multiple linear regressions. Objective three seeks to test the effect of the internal audit quality attributes on the extent to which audit committee comply with the extent to which audit committees comply with the requirements of corporate governance in Jordan. For the purpose of regression analysis, independence and objectivity were linked with each other as they represent one factor as outlined by IIA (2016). This is also consistent with prior research in the field (e.g. Bilal, Twafik \& Bakhit, 2018; Alzeban \& Sawan, 2015; Alzeban, 2020). In addition, this is consistent with Margheim (1986), who linked competence and work performance, for example, in one factor. In respect to competence and due professional care, each dimension has its own precise indicators as outlined in IIA (2016). The competence or proficiency focuses in this study mainly on qualification and experience in accounting and related fields, training and knowledge (e.g. Zaman \& Sarens (2013); IIA, 2016; Al-Thuneibat et al., 2016; Alzeban, 2020). As shown in Table 6, the internal audit quality has three dimensions including independence and objectivity, competence and due professional care. The dependent variable is the compliance of audit committee with the governance requirements. 
Table 6. Descriptive statistics for study variables

\begin{tabular}{|l|l|l|l|l|}
\hline Variable & No. of items & Cronbach's Alpha & Mean & S.D \\
\hline Independence and objectivity & 8 & .712 & 4.3291 & .35876 \\
\hline Competence & 7 & .553 & 4.3761 & .29979 \\
\hline Due professional care & 5 & .740 & 4.3347 & .37724 \\
\hline Compliance with governance requirements & 15 & .725 & 4.3769 & .26686 \\
\hline
\end{tabular}

Table 7 shows the correlation matrix. The coefficient values are low, which indicates the absence of Multicollinearity problem among the independent variables. In addition, the correlation between the independence and objectivity dimension and the audit committee compliance is significant $(r=0.471 ; \mathrm{p}<0.01)$.

Table 7. Correlation Matrix

\begin{tabular}{|l|l|l|l|l|}
\hline Variable & Compliance & $\begin{array}{l}\text { Independence } \\
\text { and objectivity }\end{array}$ & Competence & Due professional care \\
\hline Compliance & 1 & & & \\
\hline Independence and objectivity & $.471^{* *}$ & 1 & & \\
\hline Competence & .180 & $.461^{* *}$ & 1 & \\
\hline Due professional care & .211 & $.293^{*}$ & .269 & 1 \\
\hline
\end{tabular}

**. Correlation is significant at the 0.01 level, *. Correlation is significant at the 0.05 level

Table 8 shows the results of multiple regression analysis. The results show that the model is appropriate $(\mathrm{F}=4.497 ; p=0.008)$. Cook's Distance, Centered Leverage Value, Durbin-Watson, tolerance and VIF values are all in the appropriate levels.

In respect to $\mathrm{H} 2$, the results show that independence and objectivity dimension has a positive and significant $(\mathrm{t}=3.150 ; p<0.05)$ relationship with the audit committee compliance. Therefore, $\mathrm{H} 2$ is accepted. This result is important indicator about the importance of independence and objectivity for internal auditor. However, Several studies (e.g. Goodwin \& Yeo, 2001; Sarens, De Beelde \& Everaert, 2009; Drogalas, Arampatzis \& Anagnostopoulou, 2016) stressed the importance of independence and objectivity for internal audit function to effectively contribute toward a good corporate governance practices. In this context, the findings of Desai, Roberts and Srivastava (2010) indicated that objectivity is the leader in the internal audit function quality. The significant relationship between independence and objectivity and the audit committee compliance is consistent with the findings of Goodwin and Yeo (2001) and Bilal, Twafik and Bakhit (2018). The result is also in line with the findings of several prior studies which focused on the internal audit quality and governance (e.g. Sarens et al., 2012; Suyono \& Hariyanto, 2012; Zaman and Sarens, 2013; Amin \& Burki, 2014; Tušek, 2015; Drogalas, Arampatzis \& Anagnostopoulou, 2016; Alzeban, 2020; Khalid, 2020).

Contrary to expectations, $\mathrm{H} 3$ which proposes a positive and significant relationship between internal audit competence and audit committee compliance is rejected. As shown in Table 8, the relationship between internal audit competence and audit committee compliance is 
negative and insignificant $(\mathrm{t}=-0.415, p>0.05)$. $\mathrm{H} 4$ is also rejected as the relationship between internal audit due professional care and audit committee compliance is positive but insignificant $(\mathrm{t}=0.642 ; p>0.05)$. These two results are contracted that of Bilal, Twafik and Bakhit (2018) but are in line with the findings of Zain and Subramaniam (2007) who found a weak interaction between internal auditors and audit committee in Malaysia. The justification for these insignificant results may be based on the findings of Paape et al. (2003) who justified the weak relationship between internal audit function and corporate governance due to ignoring of several governance and internal control actual practices. In this context, it could be argued that competence and due care should be actually employed by internal audit departments to effectively contribute in good corporate governance practices. In addition, these results may give indication that the members of audit committee focuses more on the independence and objectivity of internal auditor and ignores other attributes due to difficulty of monitoring them.

Table 8. Multiple regressions analysis results

\begin{tabular}{|l|l|l|l|l|l|}
\hline Independent variables & & t-value & Sig. & Tol. & VIF \\
\hline (Constant) & & 4.696 & 0.000 & & \\
\hline Independence and objectivity & & 3.150 & 0.003 & 0.756 & 1.322 \\
\hline Competence & & -0.415 & 0.680 & 0.768 & 1.303 \\
\hline Due professional care & & 0.642 & 0.524 & 0.891 & 1.122 \\
\hline $\mathrm{R}$ & 0.480 & & & & \\
\hline $\mathrm{R}^{2}$ & 0.231 & & & & \\
\hline Adjusted R & & & & & \\
\hline $\mathrm{F}$ & 0.179 & & & & \\
\hline Sig. & 4.497 & & & & \\
\hline Cook's Distance & 0.008 & & & & \\
\hline Centered Leverage Value & 0.023 & & & & \\
\hline Durbin-Watson & 0.061 & & & & \\
\hline
\end{tabular}

\section{Conclusion and Recommendations}

The current study comes to achieve several objectives. First, examining the extent to which audit committees comply with the requirements of corporate governance of Jordanian listed companies. Second, to describing the current status of internal audit quality attributes. Third, examining the relationship between the internal audit quality attributes and the extent to which audit committees comply with the governance requirements. In addition to some prior studies, the main sources of the study variables are Corporate Governance Instructions for Shareholding Companies Listed on the ASE and the International Standards for the Professional Practice of Internal Auditing. Based on response from 49 companies, the study offers valuable results, implications and recommendations. Firs, findings indicate that audit committees in Jordanian companies comply with the requirement of corporate governance and no significant difference is found in such compliance due to sector. Second, the internal audit quality indicators are met among Jordanian companies to a considerable extent. Third, the independence and objectivity dimension of internal audit quality has a positive and significant relationship with the audit committee compliance with corporate governance 
requirements. Internal audit competence and due professional care have no significant relationship with corporate governance requirements.

Based on Corporate Governance Instructions for Shareholding Companies Listed on the ASE, one important implication of the current study is the development of precise and reliable scale to measure the compliance level of audit committee with the governance requirements includes 15 practices. In addition, the independence and objectivity dimension of internal audit quality is important factor in determining the audit committee practices. Thus, board of director should additionally monitor and support such dimension through audit committees. Insignificant effect for both internal audit competence and due professional care on audit committee compliance with governance requirements is an indication of a deficiency in using the available competences and professional care attributes in internal audit functions. Therefore, a comprehensive review of the implementation mechanisms for such dimensions should be undertaken by the policy-makers in Jordanian companies.

Future studies may use larger sample to examine the audit committee compliance with governance requirement using the current study scale. In addition, future studies may incorporate other dimensions of internal audit quality to test their impact on audit committee practices. Further, qualitative study in this topic using both audit committee members and internal auditors will enrich the knowledge in the field.

\section{References}

Abbott, L. J., Daugherty, B., Parker, S., \& Peters, G. F. (2016). Internal audit quality and financial reporting quality: The joint importance of independence and competence. Journal of Accounting Research, 54(1), 3-40. https://doi.org/10.1111/1475-679X.12099

Abbott, L. J., Parker, S., \& Peters, G. F. (2012). Audit Fee Reductions from Internal AuditProvided Assistance: The Incremental Impact of Internal Audit Characteristics. Contemporary Accounting Research, 29(1), 94-118.

https://doi.org/10.1111/j.1911-3846.2011.01072.x

Abbott, L. J., Parker, S., \& Peters, G. F. (2010). Serving two masters: The association between audit committee internal audit oversight and internal audit activities. Accounting Horizons, 24(1), 1-24. https://doi.org/10.2308/acch.2010.24.1.1

Agrawal, A., \& Chadha, S. (2005). Corporate governance and accounting scandals. The Journal of Law and Economics, 48(2), 371-406. https://doi.org/10.1086/430808

Ahmad, S., \& Omar, R. (2016). Basic corporate governance models: a systematic review. International Journal of Law and Management, 58(1), 73-107.

https://doi.org/10.1108/IJLMA-10-2014-0057

AICPA. (2020). AU-C Section 610: Using the Work of Internal Auditors. Source: SAS No. 128. [Online] Available: https://www.aicpa.org/research/standards/auditattest/clarifiedsas.html

AICPA. (2014). Statement on auditing standards no. 128, using the work of internal auditors. [Online] Available: https://competency.aicpa.org/media_resources/208616-statement-on-audit 
ing-standards-no-128-using-the

Al-Thuneibat, A. A., Al-Angari, H. A., \& Al-Saad, S. A. (2016). The effect of corporate governance mechanisms on earnings management: Evidence from Saudi Arabia. Review of International Business and Strategy, 26(1), 2-32. https://doi.org/10.1108/RIBS-10-2013-0100

Alzeban, A. (2020). The relationship between the audit committee, internal audit and firm performance. Journal of Applied Accounting Research, 21(3), 437-45.

https://doi.org/10.1108/JAAR-03-2019-0054

Alzeban, A., \& Sawan, N. (2015). The impact of audit committee characteristics on the implementation of internal audit recommendations. Journal of International Accounting, Auditingand Taxation, 30(6/7), 539-559. https://doi.org/10.1016/j.intaccaudtax.2015.02.005

Amin, N., \& Burki, A. K. (2014). A study of empirical evidence of effective internal audit in corporate governance in Pakistan. International Journal of Economics and Business, 4(1), $1-20$.

Arena, M., \& Azzone, G. (2009). Identifying organizational drivers of internal audit effectiveness. International Journal of Auditing, 13(1), 43-60.

https://doi.org/10.1111/j.1099-1123.2008.00392.x

Arena, M., \& Jeppesen, K. K. (2016). Practice Variation in Public Sector Internal Auditing: An Institutional Analysis. European Accounting Review, 25(2), 319-345.

https://doi.org/10.1080/09638180.2015.1018917

Balkaran, L. (2013). Auditing the Corporate Governance Effort in an Organization. The EDP Audit, Control, and Security Newsletter (EDPACS), 48(4), 12-18.

https://doi.org/10.1080/07366981.2013.832595

Beattie, V., Fearnley, S., \& Hines, T. (2012). Do UK audit committees really engage with auditors on audit planning and performance?, Accounting and Business Research, 42(3), 349-375. https://doi.org/10.1080/00014788.2012.698090

Bilal, Z. O., Twafik, O. I., \& Bakhit, A. K. (2018). The Influence of Internal Auditing on Effective Corporate Governance in the Banking Sector in Oman. European Scientific Journal, ESJ, 14(7), 257-271. https://doi.org/10.19044/esj.2018.v14n7p257

Brown, L. D., \& Caylor, M. L. (2006). Corporate governance and firm valuation. Journal of Accounting and Public Policy, 25(4), 409-434.

https://doi.org/10.1016/j.jaccpubpol.2006.05.005

Byrne, A. (2014). Governance, Strategic Risk, Internal Audit: What Auditors Need to Know. The EDP Audit, Control, and Security Newsletter (EDPACS), 49(2), 6-14.

https://doi.org/10.1080/07366981.2014.882615

Carcello, J. V., Hermanson, D. R., \& Raghunandan, K. (2005). Changes in internal auditing during the time of the major US accounting scandals. International Journal of Auditing, 9(2), 117-127. https://doi.org/10.1111/j.1099-1123.2005.00273.x 


\section{Ml Macrothink}

Business and Economic Research ISSN 2162-4860 2021, Vol. 11, No. 2

Chambers, A. (2014). The current state of internal auditing: A personal perspective and assessment. The EDP Audit, Control, and Security Newsletter (EDPACS), 49(1), 1-14. https://doi.org/10.1080/07366981.2014.869962

Christopher, J. (2012). The adoption of internal audit as a governance control mechanism in Australian public universities - views from the CEOs. Journal of Higher Education Policy and Management, 34(5), 529-541. https://doi.org/10.1080/1360080X.2012.716001

Christopher, J., Sarens, G., \& Leung, P. (2009). A critical analysis of the independence of the internal audit function: evidence from Australia. Accounting, Auditing \& Accountability Journal, 22(2), 200-220. https://doi.org/10.1108/09513570910933942

Cohen, A., \& Sayag, G. (2010). The effectiveness of internal auditing: an empirical examination of its determinants in Israeli organizations. Australian Accounting Review No. 54, 20(3), 296-307. https://doi.org/10.1111/j.1835-2561.2010.00092.x

Coram, P., Ferguson, C., \& Moroney, R. (2008). Internal audit, alternative internal audit structures and the level of misappropriation of assets fraud. Accounting \& Finance, 48(4), 543-559. https://doi.org/10.1111/j.1467-629X.2007.00247.x

Damitio, J., Kintzele, P., Kwiatkowski, V., \& Kintzele, M. (2010). Enhanced corporate governance for restaurant companies: the role of well performing audit committees. The Journal of Hospitality Financial Management, 18(1), 33-43.

https://doi.org/10.1080/10913211.2010.10653884

Davidson, B., Desai, N., \& Gerard, G. (2013). The Effect of Continuous Auditing on the Relationship between Internal Audit Sourcing and the External Auditor's Reliance on the Internal Audit Function. Journal of Information Systems, 27(1), 41-59.

https://doi.org/10.2308/isys-50430

Davies, M. (2009). Effective working relationships between audit committees and internal audit-the cornerstone of corporate governance in local authorities, a Welsh perspective. Journal of Management \& Governance, 13(1-2), 41-73.

https://doi.org/10.1007/s10997-008-9070-9

Desai, V., Roberts, R. W., \& Srivastava, R. (2010). An Analytical Model for External Auditor Evaluation of the Internal Audit Function Using Belief Functions. Contemporary Accounting Research, 27(2), 537-575. https://doi.org/10.1111/j.1911-3846.2010.01016.x

Drogalas, G., Arampatzis, K., \& Anagnostopoulou, E. (2016). The relationship between corporate governance, internal audit and audit committee: Empirical evidence from Greece. Corporate Ownership and Control, 14(1), 569-577. https://doi.org/10.22495/cocv14i1c4art3

Ebaid, I. E. S. (2011). Internal audit function: an exploratory study from Egyptian listed firms. International Journal of Law and Management, 28(6), 495-515.

Goodwin, J. (2003). The relationship between the audit committee and the internal audit function: Evidence from Australia and New Zealand. International Journal of Auditing, 7(3), 263-278. https://doi.org/10.1046/j.1099-1123.2003.00074.x 
Goodwin, J., \& Yeo, T. Y. (2001). Two factors affecting internal audit independence and objectivity: Evidence from Singapore. International Journal of Auditing, 5(2), 107-125.

https://doi.org/10.1111/j.1099-1123.2001.00329.x

IAASB. (2013). ISA 610 (Revised 2013), Using the Work of Internal Auditors and Related Conforming Amendment. [Online] Available:

https://www.iaasb.org/publications/isa-610-revised-2013-using-work-internal-auditors-0

IIA. (2016). International standards for the professional practice of internal auditing (Standards). [Online] Available:

https://na.theiia.org/standards-guidance/Public\%20Documents/IPPF-Standards-2017.pdf

IIA Jordan. (2021). About us. [Online] Available:

https://institutes.theiia.org/sites/jordan/about/Pages/default.aspx

Jensen, M. C. (1993). The modern industrial revolution, exit, and the failure of internal control systems. The Journal of Finance, 48(3), 831-880.

https://doi.org/10.1111/j.1540-6261.1993.tb04022.x

JSC. (2017). Instructions of Corporate Governance for Shareholding Listed Companies. [Online] Available: https://jsc.gov.jo/Links2/en/instructions

Karagiorgos, T., Giovanis, N., \& Drogalas, G. (2011). Evaluation of the effectiveness of internal audit in Greek hotel business. International Journal of Economic Sciences and Applied Research, 4(1), 9-34.

Khalid, A. A. (2020). Role of Audit and Governance Committee for internal Shariah audit effectiveness in Islamic banks. Asian Journal of Accounting Research, 5(1), 81-89.

https://doi.org/10.1108/AJAR-10-2019-0075

Krenn, M. (2015). Understanding decoupling in response to corporate governance reform pressures: The case of codes of good corporate governance. Journal of Financial Regulation and Compliance, 23(4), 369-382. https://doi.org/10.1108/JFRC-04-2014-0019

Kwon, S. Y., Lee, N. R., \& Ki, E. (2014). Effects of agency costs on the relationship of corporate governance with audit quality and accounting conservatism in the Korean audit market. Asia-Pacific Journal of Accounting \& Economics, 21(2), 157-185.

https://doi.org/10.1080/16081625.2012.762970

Lélis, D. L. M., \& Pinheiro, L. E. T. (2012). Auditor and auditee perceptions of internal auditing practices in a company in the energy sector. Revista Contabilidade \& Finanças, 23(60), 212-222. https://doi.org/10.1590/S1519-70772012000300006

Maletta, M. (1993). An Examination of Auditors' Decisions to Use Internal Auditors as Assistants: The Effect of Inherent Risk. Contemporary Accounting Research, 9(2), 508-525. https://doi.org/10.1111/j.1911-3846.1993.tb00895.x

Margheim, L. L. (1986). Further evidence on external auditors' reliance on internal auditors. Journal of Accounting Research, 24(1), 194-205. https://doi.org/10.2307/2490813 
Mohamed, Z., Zain, M. M., Subramaniam, N., \& Yusoff, W. F. W. (2012). Internal audit attributes and external audit's reliance on internal audit: Implications for audit fees. International Journal of Auditing, 16(3), 268-285.

https://doi.org/10.1111/j.1099-1123.2012.00450.x

OECD. (2015). G20/OECD Principles of Corporate Governance, OECD Publishing, Paris. https://doi.org/10.1002/bl.30032

Paape, L., Scheffe, J., \& Snoep, P. (2003). The relationship between the internal audit function and corporate governance in the EU-a survey. International Journal of Auditing, 7(3), 247-262. https://doi.org/10.1046/j.1099-1123.2003.00073.x

Pathak, J. (2004). Internal audit and corporate governance: A program for information security review audit. The EDP Audit, Control, and Security Newsletter (EDPACS), 31(7), 1-13. https://doi.org/10.1201/1079/43916.31.7.20040101/79266.1

Prawitt, D. F., Sharp, N. Y., \& Wood, D. A. (2012). Internal Audit Outsourcing and the Risk of Misleading or Fraudulent Financial Reporting: Did Sarbanes-Oxley Get It Wrong?. Contemporary Accounting Research, 29(4), 1109-1136.

https://doi.org/10.1111/j.1911-3846.2012.01141.x

Prawitt, D., Sharp, N., \& Wood, D. (2011). Reconciling Archival and Experimental Research: Does Internal Audit Contribution Affect the External Audit Fee?. Behavioral Research in Accounting, 23(2), 187-206. https://doi.org/10.2308/bria-10065

Sarens, G., Abdolmohammadi, M. J., \& Lenz, R. (2012). Factors associated with the internal audit function's role in corporate governance. Journal of Applied Accounting Research, 13(2), 191-204. https://doi.org/10.1108/09675421211254876

Sarens, G., De Beelde, I., \& Everaert, P. (2009). Internal audit: A comfort provider to the audit committee. The British Accounting Review, 41(2), 90-106.

https://doi.org/10.1016/j.bar.2009.02.002

Savčuk, O. (2007). Internal audit efficiency evaluation principles. Journal of Business Economics and Management, 8(4), 275-284. https://doi.org/10.3846/16111699.2007.9636180

Stewart, J., \& Subramaniam, N. (2010). Internal audit independence and objectivity: emerging research opportunities. Managerial Auditing Journal, 25(4), 328-360.

https://doi.org/10.1108/02686901011034162

Sun, L., Johnson, G., \& Rahman, F. (2015). CFO financial expertise and corporate governance concerns: Evidence from S \& P SmallCap 600 Index. International Journal of Law and Management, 57(6), 573-581. https://doi.org/10.1108/IJLMA-08-2014-0048

Suyono, E., \& Hariyanto, E. (2012). Relationship between internal control, internal audit, and organization commitment with good governance: Indonesian case. China-USA Business Review, 11(9), 1237-1245. https://doi.org/10.17265/1537-1514/2012.09.006

Turley, S., \& Zaman, M. (2004). The corporate governance effects of audit committees. 
Journal of Management and Governance, 8(3), 305-332.

https://doi.org/10.1007/s10997-004-1110-5

Tušek, B. (2015). The influence of the audit committee on the internal audit operations in the system of corporate governance-evidence from Croatia. Economic Research-Ekonomska istraživanja, 28(1), 187-203. https://doi.org/10.1080/1331677X.2015.1028245

Vasile, E., \& Croitoru, I. (2012). The Prospects of the Internal Audit in Improving Management of Public Institutions. Internal Auditing \& Risk Management, 3(27), 1-10.

Williams, B. R., Bingham, S., \& Shimeld, S. (2015). Corporate governance, the GFC and independent directors. Managerial Auditing Journal, 30(4/5), 324-346.

https://doi.org/10.1108/MAJ-05-2014-1030

Zain, M. M., \& Subramaniam, N. (2007). Internal auditor perceptions on audit committee interactions: A qualitative study in Malaysian public corporations. Corporate Governance: An International Review, 15(5), 894-908. https://doi.org/10.1111/j.1467-8683.2007.00620.x

Zaman, M., \& Sarens, G. (2013). Informal interactions between audit committees and internal audit functions. Managerial Auditing Journal, 28(6), 495-515.

https://doi.org/10.1108/02686901311329892

\section{Appendix: Survey Questions}

Section one: Background Information (please tick $\sqrt{ }$ the appropriate box):

1. What is your gender?

Male

$\square$ Female

2. What is your age group?

$\square$ Less than 30

30-less than 40

40-less than 50

50 years or above

3. Your highest academic qualification is:

$\mathrm{PhD}$ degree

$\square$ Master degree

$\square$ Bachelor degree

$\square$ Diploma

$\square$ Secondary school

Other, please specify:

4. In which field was your degree? 


\section{MlMacrothink}

Accounting

$\square$ Business administration

$\square$ Economy

$\square$ Finance

Other, please specify:

5. What is your working position in this company?

Financial manager

Internal auditor

6. How long have you been in in this company?

Less than 5 years

5- less than 10 years

10- less than 15 years

15 - less than 20 years

20- less than 30 years

30 years or above

7. To what sector does your company belong?

Industry

Services

Banking

Insurance

\section{Section two: Audit committee compliance with the requirements of corporate governance practices of listed companies:}

Please indicate below, by circling the appropriate number, to what extent does audit committee complies with the requirements of corporate governance practices of Jordanian listed companies: $(1=$ strongly disagree; $5=$ strongly agree)

\begin{tabular}{|l|l|l|l|l|l|}
\hline Governance practice & $\begin{array}{l}\text { Strongly } \\
\text { disagree }\end{array}$ & Disagree & Neutral & Agree & $\begin{array}{l}\text { Strongly } \\
\text { agree }\end{array}$ \\
\hline $\begin{array}{l}\text { 1. All members of the Audit Committee have knowledge } \\
\text { and experience in financial and accounting issues. }\end{array}$ & 1 & 2 & 3 & 4 & 5 \\
\hline $\begin{array}{l}\text { 2. At least one of the audit committee members has an } \\
\text { academic or professional certificate in accounting, } \\
\text { finance or related fields. }\end{array}$ & 1 & 2 & 3 & 4 & 5 \\
\hline $\begin{array}{l}\text { 3. The audit committee discusses matters related to the } \\
\text { nomination of the external auditor, ensures that he fulfils } \\
\text { all the requirements specified in legislations, and makes } \\
\text { sure that there is nothing affects his independence. }\end{array}$ & 1 & 2 & 3 & 4 & 5 \\
\hline $\begin{array}{l}\text { 4.The audit committee discusses and monitors } \\
\text { everything related to the work of the external auditor, } \\
\text { including his work plan. }\end{array}$ & 1 & 2 & 3 & 4 & 5 \\
\hline $\begin{array}{l}\text { 5. The audit committee monitors the company's } \\
\text { management response to the external auditor comments, } \\
\text { and accordingly makes recommendations to the board of }\end{array}$ & 1 & 2 & 3 & 4 & 5 \\
\hline
\end{tabular}


directors.

6. The audit committee examines the periodic reports prior to their presentation to the board of directors, and makes recommendations in this regard, with emphasis on any change in the accounting policies and accounts due to the auditing or the suggestions of the external auditor.

7. The audit committee studies and evaluates the internal control and auditing procedures.

8. The audit committee reviews the external auditor's evaluation of internal control and auditing procedures.

9. The audit committee reviews the internal auditor's reports, with emphasis on any violations due to the internal auditor's work.

10. The audit committee recommends to the board of directors regarding internal control, internal audit and the internal auditor work.

11. The audit committee takes all the necessary procedures to ensure that no conflict of interest may arise from the company's transactions, contracts or projects with related parties.

12. The audit committee reviews the related parties' transactions and recommends to the board of directors prior to their ratification by the company.

13. The audit committee sets out the polices and strategies necessary to improve the internal control in the company.

14. The Audit Committee recommends to the board of 1 directors to nominate the external auditor for election by the General Assembly.

15. The Audit Committee recommends to the Board of Directors to appoint an internal auditor for the Company.

\begin{tabular}{|c|c|c|c|c|}
\hline & & & & \\
\hline 1 & 2 & 3 & 4 & 5 \\
\hline 1 & 2 & 3 & 4 & 5 \\
\hline 1 & 2 & 3 & 4 & 5 \\
\hline 1 & 2 & 3 & 4 & 5 \\
\hline 1 & 2 & 3 & 4 & 5 \\
\hline 1 & 2 & 3 & 4 & 5 \\
\hline 1 & 2 & 3 & 4 & 5 \\
\hline 1 & 2 & 3 & 4 & 5 \\
\hline 1 & 2 & 3 & 4 & 5 \\
\hline 1 & 2 & 3 & 4 & 5 \\
\hline
\end{tabular}

\section{Section three: Internal Audit Function Quality:}

Please indicate below, by circling the appropriate number, to what extent does your company committed to the following internal audit function quality indicators: (1=strongly disagree; $5=$ strongly agree)

\begin{tabular}{|l|l|l|l|l|l|}
\hline Objectivity & $\begin{array}{l}\text { Strongly } \\
\text { disagree }\end{array}$ & Disagree & Neutral & Agree & $\begin{array}{l}\text { Strongly } \\
\text { agree }\end{array}$ \\
\hline $\begin{array}{l}\text { 1. The internal auditors have not any personal interests } \\
\text { in the company. }\end{array}$ & 1 & 2 & 3 & 4 & 5 \\
\hline $\begin{array}{l}\text { 2. The internal auditors can easily and impartially } \\
\text { perform their duties in the company. }\end{array}$ & 1 & 2 & 3 & 4 & 5 \\
\hline $\begin{array}{l}\text { 3. The company has full confidence that the internal } \\
\text { auditors are doing their job perfectly. }\end{array}$ & 1 & 2 & 3 & 4 & 5 \\
\hline $\begin{array}{l}\text { 4. The internal auditors can easily access to records, } \\
\text { personnel and properties of the company. }\end{array}$ & 1 & 2 & 3 & 4 & 5 \\
\hline $\begin{array}{l}\text { 5. The company offers the sufficient funds for the } \\
\text { internal auditors to perform their duties effectively. }\end{array}$ & 1 & 2 & 3 & 4 & 5 \\
\hline Competency & 1 & 2 & 3 & 4 & 5 \\
\hline $\begin{array}{l}\text { 6. The internal auditors have qualifications in } \\
\text { accounting or related fields. }\end{array}$ & 1 & 2 & 3 & 4 & 5 \\
\hline
\end{tabular}




\begin{tabular}{|l|l|l|l|l|l|}
\hline $\begin{array}{l}\text { 7. The internal auditors have sufficient experience in } \\
\text { accounting and auditing. }\end{array}$ & 1 & 3 & 4 & 5 \\
\hline $\begin{array}{l}\text { 8. Some of the internal auditors members have } \\
\text { appropriate professional certificates. }\end{array}$ & 1 & 2 & 3 & 4 & 5 \\
\hline $\begin{array}{l}\text { 9. The Internal auditors have adequate knowledge to } \\
\text { evaluate various types of risks. }\end{array}$ & 1 & 2 & 3 & 4 & 5 \\
\hline $\begin{array}{l}\text { 10.Some internal auditors have adequate knowledge of } \\
\text { the major IT risks and technology-based audit methods } \\
\text { available to perform their duties. }\end{array}$ & 1 & 2 & 3 & 4 & 5 \\
\hline $\begin{array}{l}\text { 11. Internal auditors participate in ongoing education } \\
\text { and training courses. }\end{array}$ & 1 & 2 & 3 & 4 & 5 \\
\hline $\begin{array}{l}\text { 12. Internal auditors have sufficient knowledge in the } \\
\text { accounting and auditing standards. }\end{array}$ & 1 & 2 & 3 & 4 & 5 \\
\hline Due professional care & 1 & 2 & 3 & 4 & 5 \\
\hline $\begin{array}{l}\text { 13. The internal auditors determine the extent of work } \\
\text { needed to achieve the auditing objectives. }\end{array}$ & 1 & 3 & 4 & 5 \\
\hline $\begin{array}{l}\text { 14. The internal auditors evaluate the sufficiency and } \\
\text { effectiveness of governance, risk management, and } \\
\text { control processes. }\end{array}$ & 1 & 2 & 3 & 4 & 5 \\
\hline $\begin{array}{l}\text { 15. The internal auditors evaluate the possibility of } \\
\text { major errors, fraud, or noncompliance. }\end{array}$ & 1 & 2 & 3 & 4 & 5 \\
\hline $\begin{array}{l}\text { 16. The internal auditors evaluate the cost of any } \\
\text { procedure against its expected benefits. }\end{array}$ & 1 & 3 & 4 & 5 \\
\hline $\begin{array}{l}\text { 17. The internal auditors use the technology-based } \\
\text { audit and other data analysis techniques. }\end{array}$ & 1 & 2 & 4 & 5 \\
\hline
\end{tabular}

\section{Section four: Internal Auditor Independence:}

Please indicate below, by circling the appropriate number, to what extent do you agree with the following internal auditor independence indicators: (1=strongly disagree; $5=$ strongly agree)

\begin{tabular}{|l|l|l|l|l|l|}
\hline Independence & $\begin{array}{l}\text { Strongly } \\
\text { disagree }\end{array}$ & Disagree & Neutral & Agree & $\begin{array}{l}\text { Strongly } \\
\text { agree }\end{array}$ \\
\hline $\begin{array}{l}\text { 1. There are no restrictions to limit the ability of } \\
\text { internal auditors to do their work without any bias. }\end{array}$ & 1 & 2 & 3 & 4 & 5 \\
\hline $\begin{array}{l}\text { 2 The internal auditors report directly to the board of } \\
\text { director. }\end{array}$ & 1 & 2 & 3 & 4 & 5 \\
\hline $\begin{array}{l}\text { 3. There is nothing that may impair in fact or } \\
\text { appearance the independence of the internal auditor. }\end{array}$ & 1 & 2 & 3 & 4 & 5 \\
\hline
\end{tabular}

\section{Copyright Disclaimer}

Copyright for this article is retained by the author(s), with first publication rights granted to the journal.

This is an open-access article distributed under the terms and conditions of the Creative Commons Attribution license (http://creativecommons.org/licenses/by/4.0/). 